\title{
ANGPTL1 wt Allele
}

National Cancer Institute

\section{Source}

National Cancer Institute. ANGPTL1 wt Allele. NCI Thesaurus. Code C106474.

Human ANGPTL1 wild-type allele is located in the vicinity of $1 \mathrm{q} 25.2$ and is approximately $22 \mathrm{~kb}$ in length. This allele, which encodes angiopoietin-related protein 1, plays a role in the regulation of hematopoietic stem cells. 